\title{
THE NEEDS ANALYSIS OF SENIOR HIGH SCHOOL STUDENTS' READING COMPETENCE IN NATIONAL EXAMINATION: STUDENTS' PERSPECTIVE
}

\author{
Ari Mayang \\ Sebelas Maret University \\ ari.mayang@gmail.com \\ Joko Nurkamto \\ Sebelas Maret University \\ jokonurkamto@gmail.com \\ Nur Arifah Drajati \\ Sebelas Maret University \\ drajatinur@gmail.com
}

\begin{abstract}
The focus of this research is to assess the Reading competence needs of senior high school students in English National Examination (ENE) based on students' perspective. The background in conducting this research mainly because of two things. The first one is the importance of curriculum evaluation behind the Needs Analysis itself. The second one is the importance of the certain preparation for strengthening English material to face the English National Examination. Both of these backgrounds are equally important for students and teachers at once. The research questions of this study are framed within the scope of students' perspective. The method of this research included some of questionnaires which was then analyzed using the five-points Likert Scale method. This research already debriefed 106 senior high school students in grade 12 from Boyolali regency, Central Java. They were involved in filling out the questionnaire where the results were used as the main data in this study. The final findings in this study include the fact that: (1) The Reading questions in National Examination are in moderate level of difficulty based on the students perspective, (2) The Reading National Examination materials are clearly taught by the teachers, (3) Reading is very important material to be mastered in National Examination, (4) The students are in moderate level dealing with their mastery of Reading material in National Examination, (5) The use of technology in Reading material learning is very important method based on students' perception, and (6) The frequency of use of technology in Reading lessons by teachers is quite often (moderately) based on student opinions.
\end{abstract}

Keywords: Reading Competence, Needs Analysis, English National Examination, Students' Perspective

\section{A. INTRODUCTION}

English test such as English National Examination (ENE) in Indonesia has become the part of English for Specific Purposes (ESP). In principle, each ESP test is classified as a performance test that aims to assess certain skills needed to succeed in language (Tratnik, 2008, p. 5). As a conclusion, English test in Indonesian National Examination may defined as an English 
performance test held by the central government to measure and evaluate the students' competence nationally that aims to assess certain skills needed to succeed in English language.

This exam began the first time in 1950 until now and has undergone many changes. Because the important position of the exam as one of the parameters of student graduation, the school places National Examination in very important events, and compete to provide training and special preparation to deal with it. English as one of the subjects tested in the National Exam also received special attention, especially by teachers. English teachers must work hard to support students, therefore they can pass the test based on the standard that could bring graduate, to achieve this, the teachers took various research and development from English language learning in the classroom. One product that can be used to prepare the condition of students who are ready to face the National Exam in English is to conduct a Needs Analysis study in the classroom. To find out the level of the students' needs in terms of having the English language competence to face the National Examination, a Needs Analysis study can be used to answer the question. Needs analysis studies for a long time can be used at the ESP level (English for Specific Purposes). Needs Analysis - also known as needs assessment - is believed to be an integral part of curriculum development and holds a not-so-simple role in the process of developing and implementing language courses, either English for Specific Purposes (ESP) or General English courses (GE) (Alqunayeer \& Zamir, 2016, p. 87). These things above make the writer interested in raising the theme of the Needs Analysis and National Examination.

Furthermore, some previous studies on the theme of reading Needs Analysis have been conducted by the experts and researchers. Sahar Fadel and Tariq Elyas in 2015 conducted a study at King Abdul Aziz University and found that the additional reading university program was still too little and the students were willing to have additional reading programs to improve their reading proficiency (Fadel \& Elyas, 2015, p. 26). Edy Wahyono \& Dewi Puspitasari in 2015 held a research to students in Hasanuddin University and found that students want to further enhance their understanding of reading lessons and want to apply several reading strategies so that their EAP learning becomes more effective and efficient (Wahyono \& Puspitasari, 2015, p. 1013). S.Salam in 2017 held a research to describe the need of development of 'Reading Comprehension' teaching materials to students and lecturers of Indonesian Language and Literature Education Department, Gorontalo and it is found that the Reading teaching materials used in the program not in accordance with the needs of students (Salam, 2017, p.112). A kind of reading research of first-year students at 
the University of Pretoria Sociology Department by Naomi Adjoa Nana Yeboah Boakye and Magdaline Mbong Mai in 2016, found that students tended to worry about not being able to understand the reading module because the module was not offered in the home language (Boakye, 2016, p.244).

Meanwhile in the scope of National Examination, Nanang Zubaidi \& Budi Tiara Novitasari in 2014 conducted research from several volunteer students in Yogyakarta. The findings said several suggestions based on students' needs, namely: English National Exams must be completed with progress-based assessments; English National Examination must evaluate four students' language skills and their current language acquisition; and the English National Examination must be designed to suit the educational situation and school facilities as well as the conditions of the students themselves (Zubaidi \& Novitasari, 2014, p.6).

This research adopted Jack Richards's approach of Needs Analysis as the Grand Theory. In 2010 Jack C. Richards, through his book "Curriculum Development in Language Teaching" detailed the componets of Needs Analysis. The components he described such as: the purpose of Needs Analysis, the definition of needs, the users of Needs Analysis, the target population in Needs Analysis, and the examples of Needs Analysis. The other units he explained are procedure for conducting Needs Analysis and activities in Needs Analysis. Richards also mentioned the steps how to administering Needs Analysis, how to design Needs Analysis, how to use the information obtained in Needs Analysis, and also how to discuss questions (Richards, 2010, p. 52-71). This research is conducted mainly for answering the problem statements:

Q1. How easy the National Examination Reading questions can be answered by students based on their perspective?

Q2. How clear Reading National Examination material is taught by the teachers?

Q3. How important is Reading material to be mastered to face the National Examination?

Q4. How good are the students in Reading material to face the National Examination?

Q5. How important is the use of technology in Reading material learning for National Examination?

Q6. How often do teachers use technology in Reading material learning for National Exam Preparation? 


\section{B. LITERATURE REVIEW}

\section{Definition of need analysis}

Many experts began to use Needs Analysis research as the subject of their study. They are also began to define Needs Analysis based on their respective understanding. According to Jack C. Richards (Richards, 2010, p. 51), Needs Analysis is defined as certain procedures are used to collect data and documents about the needs of students. Richards added, Needs are often described as linguistic deficiencies, that is, describing the differences between what today's learners can do in the context of their language skills and what they should be able to do (2010, p. 54). Richards also underlined, that Needs here are often explained in terms of language needs, that is, as language skills needed to survive in a society that demands a dominance or English ability (2010, p. 55).

Moreover, Nunan (1994, p. 54) argues that Need Analysis is a set of procedures for determining parameters or measuring instruments of a study program. J.D. Brown defined needs analysis (NA) as systematic collection and analysis of various subjective and objective information needed to determine and validate the objectives of a sustained curriculum that meets the requirements of student language learning in a particular institutional context that influences the learning and teaching situation (Brown, 1995, p. 36). Another researcher, Douglas Brown (2001, p. 35) defined Needs Analysis as activities that are based on gathering various kinds of information that will serve as a basis for developing a curriculum that will meet the learning needs of groups of students on certain courses. While according to Iwai et al. (1999), Needs Analysis as the activities that are involved in collecting information that will serve as the basis for developing a curriculum that will meet the needs of a particular group of students. From the definitions above we may conclude that Needs Analysis is a set of systematic process \& activities to gather subjective and objective information to define, validate and find out the main needs of learners or groups of learners that satisfy the language learning requirements of students that will serve as the basis for developing a curriculum.

\section{Purpose of needs analysis}

Jack C. Richards (Richards, 2010, p. 52) described that Needs Analysis in language teaching may be used for a number of different purposes, for examples:

a. To see what language skills are needed by learners when performing certain roles.

b. As a guide in determining whether the course has been able to meet the needs of the students.

c. To sort and classify students in groups based on their individual language skills training needs. 
d. To find out the change in goals that people feel is important in a course.

e. To find out the gap between what can be done and what must be done by students.

f. To identify data about problems that are potentially experienced by students.

\section{The users of needs analysis}

According to Richards (2010, p. 55), Needs Analysis can be applied to a variety of different users. For example, in a needs analysis activity to revise a secondary school English curriculum in a country, the end-users of the study may include:

a. Curriculum compilers at the ministry of education, who will use the information to evaluate the suitability of the syllabus, curriculum, and material specified.

b. Teachers who will teach and will use the new revised curriculum.

c. Students, who will be taught from the latest revised curriculum.

d. The writers, who are preparing new textbooks for publication and will be used by students.

e. School curriculum holders, who are involved in developing school final assessments.

f. Staff of school institutions, who are interested in knowing what level is expected of students who leave school and what problems they will potentially face.

\section{The target population of needs analysis}

According to Richards (2010, p. 57) the definition of the target population in the Needs Analysis is to refer to who the information will be collected. These people can consist of language learners who can provide useful information in meeting the needs analysis objectives. For example, in a Needs Analysis research to determine the focus of English language programs in public secondary schools in the context of EFL, possible population targets are:
a. Policy makers
b. Ministry of education officials
c. Teachers
d. Students
e. Academics
f. Employers
g. Vocational training specialists
h. Parents
i. Influential individuals and pressure groups
j. Academic specialists 
k. Community agencies

\section{How to conduct needs analysis}

According to Richards (2010, p. 59), there are many procedures that can be used to carry out needs analysis. Information obtained on findings often depends on the type of procedure used, in this case a triangular approach (eg, gathering information from two or more sources) is recommended. Procedures for collecting information that needs analysis can be selected from the following:

\section{a. Questionnaires}

Questionnaires are one of the most frequently used instruments in Needs Analysis. This instrument is relatively easier to run. One of the advantages of this instrument is that they can be used with a large number of subjects. The advantage of this instrument is that information from this instrument is relatively easy to tabulate and to analyze (Youngshin, Youn-Jung, Doonam, 2015, p. 323). This instrument is also commonly used to find information about various types of linguistic problems including language usage, communication difficulties, preferred learning styles, preferred classroom activities, and attitudes and beliefs. Questionnaires are based on a set of structured items (where respondents choose from a number of responses) or unstructured (where open questions are given that the respondent can answer according to his choice). Structured items are usually much easier to analyze and are therefore usually preferred by researchers.

\section{b. Self-ratings}

This instrument consists of a scale used to assess a respondent's knowledge or ability. For example, a student might judge how well he can take a grammar class. The disadvantage of such an instrument is that it only provides information that is not too precise.

\section{c. Interviews}

Interviews allow us to explore problems that are more profound than questionnaires. However, interviews take longer to manage and are more suitable for small groups. Interviews are more useful in the early stages of designing a questionnaire, because it will help researchers to understand the topics and problems that exist. Interviews can be done directly with the respondent / face to face or remotely by telephone.

\section{d. Meetings}


Meetings can be a method in Needs Analysis. Meetings allow large amounts of information to be collected in a short time in one place. For example, an English teacher meeting on the topic "preparation for National Exams" may produce a variety of ideas. However, information obtained in this way leads to subjective and heterogeneous.

\section{e. Observation}

Observing student behavior as a target situation is another way to assess student needs. For example, observing students who appear in speaking classes will allow observers to arrive at certain conclusions about their language needs. However, students often do not perform well when being observed, so this problem must be taken into account and a solution sought. In addition, observation requires a special skill. Knowing how to observe, what to look for, and how to use the information obtained generally requires special and separate training.

\section{f. Collecting learner language samples}

The activity of collecting data about how well the students 'performance on a language assignment (eg, business letters, interviews, telephone calls) and documenting certain problems they have is a valuable and direct source of information about students' language needs. Language samples can be collected in the following ways:

1) written or oral tasks: Examples from students of written or oral work are collected.

2) simulation or role playing: Students are given simulations to carry out and their performance is observed or recorded.

3) achievement test: Students are tested for their abilities in various domains of language use.

4) performance tests: Students are tested for work related or task related

5) behavior, such as "how well a job interview can be done in English."

\section{g. Task analysis}

This includes the types of tasks that students must do in English. For examples do homework, handle quizzes, greet teachers in English, write emails in English.

\section{h. Case studies}

With case studies, one student or a group of selected students is observed through observational activities or relevant educational experiences. This instrument provides a very rich source of information that can supplement information obtained from other sources.

\section{i. Analysis of available information.}


In various situations where needs analysis is needed, a large amount of information needed is generally available at various sources. This includes:

1) book

2) journal articles

3) reports and surveys

4) notes and files

\section{RESEARCH METHODOLOGY}

\section{Context of the study}

\section{a. Place of the study and respondents' profile}

The research is conducted at a Senoir High School in Boyolali, Central Java. The school consists of more than 800 students and 60 teachers. While they have 26 classes divided into Science, Social, and Language program. The research used 106 respondents from 3 classes of 12 grade. They are from Social 2, Social 3, \& Social 4. The students who were the subjects of this study consisted of 35 male students and 71 female students. They are divided into 9 students aged 16 years, 73 students aged 17 years, 22 students aged 18 years, and 2 students aged 19 years.

\section{b. Time of the study}

This research submits a project to be carried out in January 2019 until March 2019 as explained in the table below.

\begin{tabular}{ll}
\hline \multicolumn{1}{c}{ Activity } & \multicolumn{1}{c}{ Month \& Year } \\
\hline Pre-survey & January 2019 \\
\hline Proposal & February 2019 \\
\hline Gathering \& analyzing the data & February 2019 \\
\hline Writing the report & March 2019 \\
\hline Submitting the data & March 2019
\end{tabular}

\section{Research design}

The research design that applied in this study is to use the Case Study approach. In accordance with what Yin said (2003: 13) Case Study research is an investigation based on direct field experience. This kind of research investigated current events within the scope of daily life by processing the sources of information obtained. In this case, the researcher collected an analysis of student needs of reading skill to deal with ENE. This study examined the Needs Analysis study 
through the perspective of the teachers as a figure who are directly involved in implementing ENE preparation at schools.

\section{Sources of the data}

Yin (2003: 85) presents there are six sources of evidence or data sources commonly used in the Case Study study. Data sources include documentation, archive records, interviews, direct observation, participant observation, and physical artifacts. Meanwhile, in this study, the data sources that are processed and used include: documentation, archive records, interviews, and direct observation.

\section{Technique of the data collection}

According to Yin (2011: 129) in qualitative research, authentic data sources may be obtained from several things, namely: interviewing, observing, collecting and examining (material) and feeling. In conducting interviews, researchers applied interviews to obtain facts about the topic surrounding ENE preparation and their opinions on the exam. Second, direct observation is conducted at each MGMP meeting to see and summarize the strategies of the teachers in preparing their students to face ENE. Meanwhile, at the stage of material collection, various types of artifacts are collected to complete the research data. This data consist of learning documents, syllabus, teacher learning plans, and daily teaching journals.

\section{FINDINGS AND DISCUSSION}

\section{Findings}

The researcher has asked the students to fill out a questionnaire about the students' needs regarding the English National Examination (ENE). The results of each research question are as follows:

Q1. How easy the National Examination Reading questions can be answered by students based on their perspective?

Q2. How clear Reading National Examination material is taught by the teachers?

Q3. How important is Reading material to be mastered to face the National Examination?

Q4. How good are the students in Reading material to face the National Examination?

Q5. How important is the use of technology in Reading material learning for National Examination?

Q6. How often do teachers use technology in Reading material learning for National Exam Preparation? 
Volume 5, Number 01, June 2019

Tables and figures below represent the perceptions of senior high students in Boyolali regarding the topic above.

Table 1. The Students Perspective of Reading Competence in National Examination

\begin{tabular}{ccc}
\hline QUESTIONS & MEAN & DESCRIPTION \\
\hline Q1 & 2,75 & Moderately \\
\hline Q2 & 3,04 & Clear \\
\hline Q3 & 4,75 & Very Important \\
\hline Q4 & 2,97 & Moderately \\
\hline Q5 & 4,07 & Very Important \\
\hline Q6 & 2,75 & Moderately \\
\hline
\end{tabular}

Figure 1. The Students Perspective of Reading Competence in National Examination

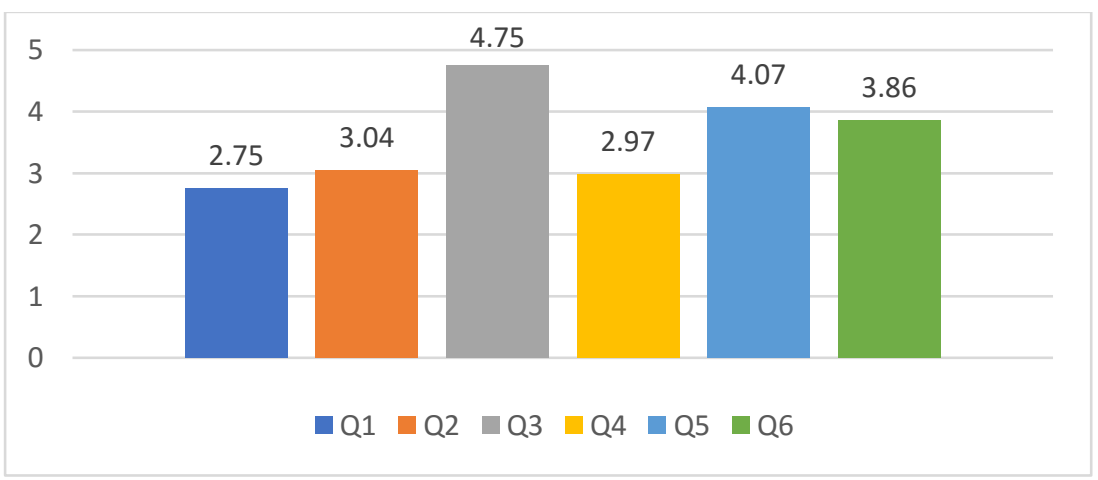

As table 1 and figure 1 show, we may find the answers of the problem statements of this research, they are:

a. The Reading questions in National Examination are in moderate level of difficulty based on the students perspective.

b. The Reading National Examination materials are clearly taught by the teachers.

c. Reading is very important material to be mastered in National Examination.

d. The students are in moderate level dealing with their mastery of Reading material in National Examination.

e. The use of technology in Reading material learning is very important method based on students' perception.

f. The frequency of use of technology in Reading lessons by teachers is quite often (moderately) based on student opinions. 


\section{Arie Mayang Koesoema Adhi, The Needs Analysis of Senior High School...}

\section{Discussion}

As explained in the beginning of this paper that Needs Analysis functions as part of curriculum development. Iwai (1999, p. 7 in Albassri, 2016, p. 78) defined Needs Analysis as the process of gathering information in relation to language that, in return, is the basis for adapting a curriculum to meet the learning needs of a specific group of students. As stated by John McAlister (2010), Needs Analysis was born for the intent of the course's objectives and curriculum. It analyses what needs the learners have understood and what they need to get. Needs Analysis is in charge of ensuring that the course will consist of the relevant subject and appropriate to be reviewed. Good Needs Analysis contains a list of pertinent questions and at the same time finds the answers with the most efficient techniques (McAlister, 2010, p. 24). That is why the Needs Analysis research on Reading material needs to be done so that the teachers get sufficient information about appropriate tips and tricks in teaching English for the sake of the success of the National Examination.

This paper has taken the findings that the use of technology is very important in Reading learning. This is in line with the results of research from Pearson, Ferdig, Blomeyer, \& Moran (2005) that wide range of digital technologies appear to enhance the Reading performance of the students.

\section{E. CONCLUSION AND SUGGESTION}

\section{Conclusion}

Reading material in the National Examination is at a moderate level of difficulty based on the student's perspective. Nevertheless the material for reading the National Examination according to students has been clearly taught by the teacher. This indicates that there is a little inconsistency between the material taught by the teacher and the National Examination material issued by the

government. Or at least the teacher must improve the quality of his teaching so that the Reading problem becomes easy for students to do.

Meanwhile students say that Reading is very important material to be mastered in the National Examination but nevertheless students feel they are only at a moderate level in relation to mastery of Reading competence.

Furthermore, the use of technology in learning Reading materials is a very important method based on student perceptions but the frequency of technology use in reading lessons by teachers is still in the middle level based on student opinions. This should be a concern for teachers to more often involve the use of technology in their Reading class. 
Volume 5, Number 01, June 2019

\section{Suggestion}

From the conclusion above can be taken a recommendation that teachers should focus more on their teaching on Reading material because the material covers $70 \%$ of the National Examination questions.

The second recommendation is that teachers should increase the use of technology in the classroom, which is expected to increase students 'reading motivation and improve students' reading skills so that they are ready to face the National Examination.

\section{REFERENCES}

Albassri, I., A. (2016). Needs-Analysis-Informed Teaching for English for Specific Purposes. Electronic Theses, Projects, and Dissertations. Paper 274.

Alqunayeer, H., S., \& Zamir, S. (2016). Needs Analysis of Saudi EFL Female Students: A Case Study of Qassim University. Journal of Curriculum and Teaching Vol. 5, No. 1; pp. 87-104, 2016.

Boakye, N., A., N., Y., \& Mai, M., M. (2016). A Needs Analysis for a Discipline-Specific Reading Intervention. Canadian Center of Science and Education. English Language Teaching Vol. 9, No. 3; 2016 ISSN 1916-4742 E-ISSN 1916-4750. ISSN 1916-4742 E-ISSN 1916-4750.

Brown, H. D. (2001). Teaching by Principles: An Interactive Approach to Language Pedagogy. New York: Addison Wesley Longman.

Brown, J. D. (1995). The elements of language curriculum: A systematic approach to program development. Boston: Heinle and Heinle.

Cowling, J. D. (2007). Needs analysis: Planning a syllabus for a series of intensive workplace courses at a leading Japanese company. English for Specific Purposes, 26, 426-442.

Fadel, S., \& Elyas, T. (2015). ESP Needs Analysis to Integrate a Scientific Reading Program in the English Language Institute at King AbdulAziz University. International Journal of Educational Investigations. Vol.2, No.4: 14-27, 2015 (April).

Iwai, T., Kondo, K., Limm, S. J. D., Ray, E. G., Shimizu, H., and Brown, J. D. (1999). Japanese language needs analysis. Available at: http://www.nflrc.hawaii.edu/Networks/NW13/NW13.pdf

McAlister, J. (2010). Language Curriculum Design. New York: Routledge.

Muharni. (2017). The Influence of Grammar and Vocabulay Mastery on Students' Reading Comprehension at Language Development Center of UIN SUSKA Riau. J-SHMIC, Journal of English as Academic. DOI: https://doi.org/10.25299/jshmic.2017.vol4(1).508 
Nunan, D. (1994). The learner-centered curriculum. Cambridge: Cambridge University Press.

Nunan, D. and Lamb, C. (1996). The Self-Directed Teacher. Cambridge: Cambridge University Press.

Pearson, P \& Ferdig, Richard \& Jr., Robert L, Blomeyer, \& Moran, Juan. (2005). The Effects of Technology on Reading Performance in the Middle-School Grades: A Meta-Analysis With Recommendations for Policy. Learning Point Associates / North Central Regional Educational Laboratory (NCREL).

Richards, J., C. (2010). Curriculum Development in Language Teaching. Cambridge: Cambridge University Press.

Salam, S. (2017). Developing Needs Analysis Based-Reading Comprehension Learning Materials: A Study on the Indonesian Language Study Program Students. Australian International Academic Centre PTY.LTD.

http://dx.doi.org/10.7575/aiac.alls.v.8n.4p.105

Tratnik, A. (2008). Key Issues in Testing English for Specific Purposes. Scripta Manent 4 (1). 3-13.

Wahyono, E., \& Puspitasari, D. (2015). Students' Need Analysis Of English Reading Skills for Academic Purposes. Prosiding ICTTE FKIP UNS 2015. Vol 1, No 1, January 2016.

Yin, K., R. (2003). Case Study Research - Design \& Methods, Third Edition. London: Sage Publication. Volume 5.

Yin, K., R. (2011). Qualitative Research from Start to Finish. New york: The Guilford Press.

Youngshin, S., Youn-Jung, S., \& Doonam, O. (2015). Methodological Issues in Questionnaire Design. J Korean Acad Nurs Vol.45 No.3, 323- 328.

http://dx.doi.org/10.4040/jkan.2015.45.3.323

Zubaidi, N., \& Novitasari, B., T. (2014). Ideal vs Practice of Indonesian Senior High School National Exam of English Subject: Students' Perception. Conference Paper. June 2014. https://www.researchgate.net/publication/263393377. 